\title{
The Mackie Ethnological Expedition to Central Africa.
}

\section{$\mathrm{T}$} HE REV. J. ROSCOE, the leader of the Mackie Ethnological Expedition to Central Africa, has recently returned to this country after an absence of more than eighteen months. The expedition, which was made possible by a generous donation from Sir Peter Mackie, placed at the disposal of the Royal Society, had for its object the investigation of the laws, customs, and beliefs of the native tribes under British rule in Central Africa, particularly in the Uganda Protectorate, in accordance with a scheme which had been planned and urgently advocated for many years by Sir James Frazer, but for which funds had hitherto been wanting. The tribes which the expedition proposed to investigate had been very little modified by contact with civilisation, and it was felt that a detailed examination of their institutions and beliefs would not only add very materially to our scientific knowledge, but would also conduce to the good government and economic development of the country in the future.

The expedition left this country in the spring of I9I9. The first part of its labours was devoted to the study of the Bahima of Ankole, an important pastoral tribe, in the western part of the Uganda Protectorate. During a stay of three months Mr. Roscoe gathered an immense amount of detailed information relating to the clan and totem organisation and tabus, the system of government, and the beliefs and rituals connected with the care of cattle and the milk, which play an important part in regulating the life of the community.

From Ankole the expedition moved to Kigezi, where a short stay was made for the purpose of studying the Bakyiga, a large and fierce mountain tribe of many clans, partly pastoral, partly agricultural. The tribe is believed to be the original stock, which the Bahima were never able to conquer. This is borne out by the fact that they are of the same type as the slaves in Ankole and the lower order of people in Bunyoro.

On leaving Kigezi the expedition set out for Bunyoro, proceeding westward to the arm connecting the two lakes Edward and George, and then northward along the line of these lakes and Lake Albert-a country very little known, which was found to be of extraordinary beauty.
In the course of a short rest of a week a superficial examination of the Bamba and Bakonja of Mount Luenzori was made. The expedition then proceeded from Port Ntoroko by steamer to Butiaba, the port for Masindi, the capital of Bunyoro, where it entered upon the second and, as it proved, the most fruitful part of its labours.

The King of Bunyoro gave every assistance to the expedition. He is now a Christian, but as the repository of the tradition and practice of the religion of the people his knowledge, which was placed freely at Mr. Roscoe's disposal, proved of inestimable value. The Bunyoro tribe, or rather nation, consists of two distinct races, the Bahuma and the Bairu-the latter a subject people of agricultural peasants belong. ing to Bantu stock and descended from the original inhabitants of the country; the former a purely pastoral people akin to the Gallas, who form a ruling aristocracy, descended from a people which invaded and conquered the country from the north. Intermarriage between the two races is rare, though not absolutely forbidden. The greater part of the life of the king is, or rather used to be, devoted to ceremonial observances connected with his cattle in order to increase the progeny of man and beast and the supply of food. So much was this the case that the whole of his day was mapped out for him, and he rarely, if ever, quitted his kraal. One peculiar feature of the ritual was a daily meal at which he partook of sacred beef. The royal cook knelt before the king and placed four pieces of meat in the king's mouth with a special fork, taking care not to let the fork touch the roval teeth under penalty of death.

From Masindi the expedition proceeded to Mount Elgon, where it made some further inquiries among the cannibal Bagesu, whom Mr. Roscoe had already visited and described. It had been intended originally to pass northward into Karamojo in order to investigate the Turkana, an interesting people, remarkable for their great stature, of whom very little in detail is known. Unfortunately, military operations which were being carried on in that region made that impossible. The expedition therefore turned to Busoga, and after a short stay there returned to Bunvoro, whence it started on its homeward iourney down the Nile.
E. N. F.

\section{The Indian School of Mining and Geology.}

THE recent decision of the Government of India to establish a School of Mining and Geology at Dhanbaid follows the recommendations of Sir Duncan McPherson's Committee of I $^{1} 3^{-14} 4$ on mining education, of the expert Committee which examined the system of mining education in England in $1914-4_{5}$, and of the Indian Industrial Commission of 1916-18. The site of the proposed school has caused some difference of opinion in the past. Thus the Calcutta University Commission enumerated the many advantages which Calcutta was believed to possess, but in finally deciding on Dhanbaid the Government of India has followed the recommendations of the three Committees, and come to a conclusion with which those who know local conditions best will cordially agree. Dhanbaid enjoys an excellent situation, and return visits to the coal-mines will occupy onlv a few hours; from Calcutta they would take at least thirty-six hours.

The provision at present made for mining education No. 2666 , VOL. IO6] in India comprises (I) courses at the Sibpur Engineering College, near Calcutta, and (2) evening classes on the coalfield. The existing provision for higher training in geology is even less satisfactory. The proposal is that the new school will be an institution of collegiate type, in which the highest form of teaching in the art of mining and its accessory sciences is to be undertaken, so that in time it will rank with similar institutions in this country, and give equal opportunities for the study of geology and mining in all their branches. Thus natives of India will eventually be able to obtain in their own country that specialised training which to-day is an essential qualification for the more responsible posts in the mining and geological professions.

With the school on the coalfield both students and staff will be in close contact with a well-developed mining industry, and the great desirability of having intimate relationship between the industry and mining education will be realised. Further, the teachers of 
the evening classes, who undertake part of the work of imparting elementary mining education at present, will be enabled to keep themselves au courant with the latest developments and to obtain advice and assistance from the school.

The Central Government will assume responsibility for its maintenance and administration, as the development of India's mineral industry is an Imperial undertaking which affects vitally the general advancement of the country as a whole. Under the Reforms Scheme only central agencies and institutions for research and for professional or technical training or for the promotion of special studies will be under the Government of India, as it is only for such that funds can be allotted from the Imperial revenues.

The fact that both coal and metalliferous mines are now being developed in other Provinces is not lost sight of. The school will be open to students from all parts of British India, and facilities are to be provided for others from the Indian States. Although the school will supply trained officials for the coal-mining industry, it has been definitely laid down that instruction in metalliferous mining shäll receive due attention. It is hoped that provincial Governments, mining associations, and the great mining companies of India will give liberal support to the school by the institution of scholarships, travelling fellowships, and lectureships.

Elementary instruction in coal and metalliferous mining is not one of the objects of the school; this will receive due care from the provincial Governments concerned. A final decision has not yet been reached with regard to the higher training of mine surveyors, which is left for the future consideration of the governing body. Should a metallurgical institute be established in the future at Jamshedpur, full arrangements are to be made for the interchange of facilities in research and advanced training between it and the new School of Mines and Geology.

The school will not be affiliated to any university. at least in its initial stages, though it must, of course, maintain touch with the highest form of educational thought, methods, and standards. Both the Universities of Calcutta and Patna will be represented on the governing body. The latter consists of fourteen members, presided over by the Director of the Geological Survev of India. Other official members are the Chief Inspector of Mines, the principal of the college, and the representatives of the Governments of Bengal and of Bihar and Orissa. The rest are non-officials, appointed bv the mining associations. etc., of various parts of India, and the two universitv members already mentioned.

Steps have already been taken to acquire a suitable site at Dhanbaid, and the governing body is to formulate proposals at onre for buildings and equipment. staff, courses of studv. and examinations, rules of admission and an estimate of the initial and recurring costs of the school.

J. C. B.

\section{University and Educational Intelligence.}

Cambridge.-Mr. A. B. Appleton (Downing College), Mr. D. G. Reid (Trinity College), and Mr. A. Hopkinson (Emmanuel College) have been appointed demonstrators in anatomy, and $\mathrm{Mr}$. A. Hutchinson (Pembroke College) has been re-appointed demonstrator in mineralogy and assistant curator of the museum of mineralogy. It is proposed that Dr. Myers should be appointed reader in experimental psychology, and that the University lectureship which he now holds should cease.

NO. 2666, VOL. I06]
A LECTURE on "Recent Developments in Astronomy," in connection with the London County Council's lectures for teachers, will be given by Prof. A. Fowler at the Regent Street Polytechnic, W.I, on Saturday morning, December 4, at 10.30 o'clock. The chair will be taken by $\mathrm{Mr}$. E. Walter Maunder.

THE Toronto correspondent of the Times stated on November 25 that, including the grant of $1,000,000$ dollars from the Government of the Province of Quebec and I,000,000 dollars from the Rockefeller Foundation, the McGill University centennial endowment fund has reached the total of 6,32I,000 dollars (approximately $1,580,000 l$.), which exceeds the amount the recent campaign was started to raise.

An exchange of university students between Belgium and the United States has recently been made; twenty-four Belgian students have been admitted to American universities and twenty-two Americans have entered Belgian universities. The exchange has been arranged and endowed by the Education Foundation of the Belgian Relief Commission from funds which remained after the Commission had completed its work in 1919. All travelling expenses of the selected students will be met from this fund, and fees will be remitted by the Belgian and some of the American universities for exchange students. In addition, Belgians entering American universities will each receive a maintenance grant of rooo dollars per annum, while American students in Belgian universities will each be allowed a sum of ro,00o francs per annum for living
expenses.

IN his presidential address to the members of the British Academy, now reprinted, Sir F. E. Kenyon discussed the subject of international scholarship. Like other societies, the Academy suffers from lack of funds, and the appeal now made for a Treasury grant will meet with the support of all who are interested in learning. The question of the resumption of relations with German scholars was considered, and while Sir F. Kenyon sees the difficulties which impede any rapprochement, he "looks forward to the revival of normal relations between English and German scholars, and I desire that it may come without delay." Meanwhile, international organisation of scholarship need not be suspended, and we can work in full accord with our Allies. As a result of a meeting held in Paris in Igra a series of proposals for future work was submitted by the representatives of the nations present. Sir F. Kenyon's review of these proposals deserves careful consideration.

THE calendar of the West of Scotland Agricultural College for the session $1920-2$ I has just been received. The college undertakes to give instruction in general agriculture, dairying, forestry, horticulture, and poultry keeping to farmers, teachers, and grocers as well as to students studying for the regular diplomas, certificates, and degrees. The course provided for farmers is held during the winter months and completed in one session; it is intended for the sons of farmers who are unable to take full-time courses. At the grocers' class, held in conjunction with the Glasgow Grocers' and Provision Merchants' Association. the lectures deal principally with milk, butter and butter-making, cheese and cheese-making, bacon, and eggs. For full-time students courses are provided which lead to college certificates and diplomas in agriculture, dairying, forestry, and horticulture and to the various national diplomas which are granted, while lectures in preparation for the degree of B.Sc. (Glasgow) are also given. The year is divided into two terms, a winter session which is held in Glasgow, and a summer session spent at the experimental 